Article

\title{
How Do Community Planning Features Affect the Place Relationship of Residents? An Investigation of Place Attachment, Social Interaction, and Community Participation
}

\author{
Heng Zhang * (i), Rodney H. Matsuoka and Yu-Jan Huang \\ Department of Architecture, National Cheng Kung University, No. 1 University Road, Tainan City 70101, \\ Taiwan; rodney0520@yahoo.com (R.H.M.); ange19074@yahoo.com (Y.-J.H.) \\ * Correspondence: changlin@mail.ncku.edu.tw; Tel.: +886-917-798-255
}

Received: 29 June 2018; Accepted: 30 July 2018; Published: 2 August 2018

check for updates

\begin{abstract}
Outdoor environment can have significant connections with place relationships. This study tried to explore the connection in detail. First, the relationship was examined through an integrated view of environmental planning, followed by reviewing impacts of essential elements from the outdoor environment on place relationships. Residents of three public housing communities in Taiwan were surveyed. Each community had a different layout: alley, cluster, and large courtyard. Exploratory factor analysis revealed that outdoor community planning features can be grouped into four factors: outdoor space quality, circulation planning, outdoor recreational facilities, and community layout. Canonical correlation analyses indicate different combinations of these factors were connected to diverse combinations of place relationship dimensions. More importantly, higher levels of satisfaction toward outdoor space quality as well as community layout were associated with greater place attachment and less community participation. Higher levels of satisfaction with circulation planning were connected to greater place attachment and community participation, and less social interaction. Multiple regression analyses found the associations between the community planning features and place relationship dimensions differed among the alley, cluster, and large courtyard. These findings can help planners and architects design public housing and similar communities that better enhance the emotional and social experiences of the inhabitants.
\end{abstract}

Keywords: place relationship; place attachment; social interaction; community participation; community planning feature; outdoor space quality; circulation planning; community layout; outdoor recreational facilities

\section{Introduction}

The interactions between characteristics of the physical environment and residents' psychological responses are of great interest to architects, landscape architects, and urban planners. Of particular importance is how outdoor community planning features affect residents' place attachment, social interactions, and community participation. The term "place relationship" will be introduced by this study to denote an overarching concept consisting of these three dimensions and describing the connections between spatial settings and people. A growing body of research has linked increases in these three dimensions with greater feelings of overall residential satisfaction, health, and quality of life [1-5]. How does satisfaction with these community planning features influence all three dimensions of residents' place relationship considered together? Surprisingly, this particular question has not been researched in depth. 
Of the studies examining the relationships between the outdoor environment and place attachment [6,7], social interaction [6,8,9], and community participation [10-12], none, to the best of our knowledge, have analyzed the effects on all three concepts at the same time. In addition, almost all of this research has been conducted at the larger neighborhood scale $[10,11,13]$. Nevertheless, planners and designers of the urban environment often focus on site scale features. These features involve those immediately surrounding public housing communities and residential apartments. How does satisfaction with the quality and layouts of these outdoor environments simultaneously influence these three concepts? What effects do circulation planning provided by outdoor walkways or parking spaces have? The answers to these questions could offer important insights into how to design outdoor environments that better meet the needs of the users. The purpose of this study, then, is an initial attempt to fill this knowledge gap.

\subsection{Place Relationship versus Other Terms}

The term sense of place has sometimes been used in this role as an overarching place concept. For these researchers, sense of place subsumes the dimensions of place identity and dependence, and sense of community $[9,11]$. However, for other researchers, sense of place encompasses place attachment, identity, and dependence [14]. In an attempt to avoid these inconsistencies and the resulting confusion, this study will use the term place relationship as the most general concept describing an individual's relationship with a place (Figure 1).

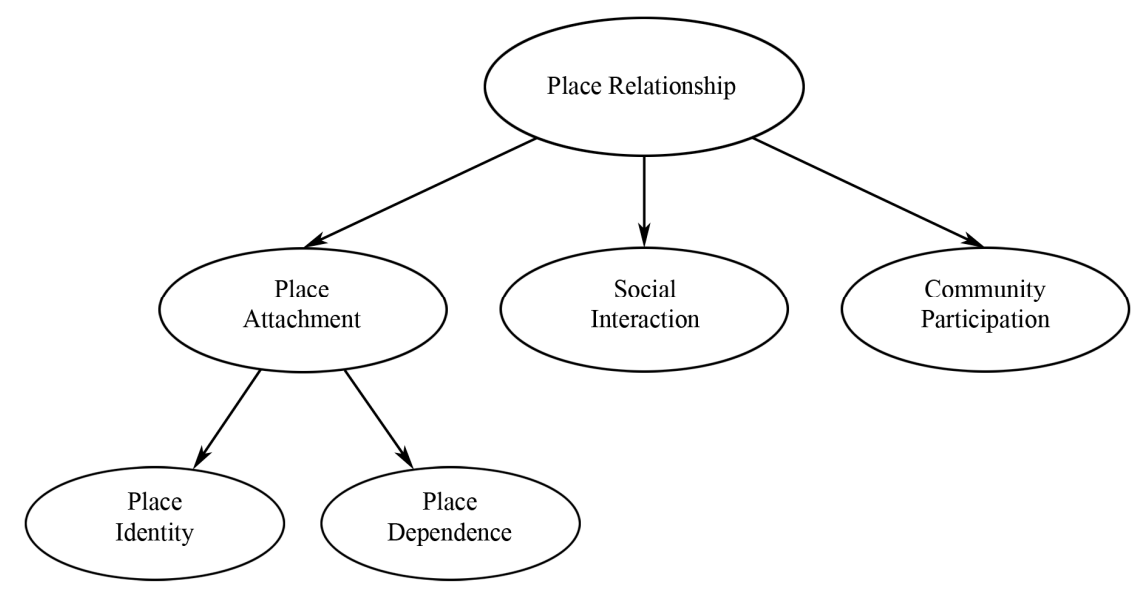

Figure 1. Model of the relationship among the major dimensions of place relationship, as defined by this study.

\subsubsection{Place Attachment}

Place attachment, as defined in the field of environmental psychology, refers to the positive affective bonds between individuals and a particular geographic locale $[15,16]$. Although many models of place attachment have been proposed, the most frequently used construct involves two underlying dimensions: place identity and place dependence [6,17].

The most used conceptualization of place identity was developed by Proshansky [18]. This concept contends that an individual's identity is defined in part by his or her relationship with the physical environment [19]. "By place-identity we mean those dimensions of self that define the individual's personal identity in relation to the physical environment by means of a complex pattern of conscious and unconscious ideas, beliefs, preferences, feelings, values, goals, and behavioral tendencies and skills relevant to this environment" [18].

Place dependence, in contrast, concerns the potential of a particular setting to satisfy the needs and goals of an individual and involves an assessment of how well this setting compares with others in satisfying these needs. This comparison involves both the emotional bonds to and the activities 
afforded by a particular setting. Stokols [20] is most often credited with the development of this concept [21].

\subsubsection{Social Interaction}

Most researchers regard place attachment and social interaction as being linked, but separate concepts. The current level of understanding of the role of social interaction with relation to place has resulted from work in the field of community sociology and later in the fields of community, social, and environmental psychology. This concept centers on the interconnected social relationships that occur in a particular setting [6,22].

\subsubsection{Community Participation}

Community participation concerns various types of participation in decision-making processes that has a positive influence on an individual's community. Such participation can involve voluntary associations, groups, clubs, organizations, and societies [1,11,23]. Policymakers have aspired to increase participation particularly within disadvantaged and low-income communities, as a way to address place-based economic, social, and health inequalities [24]. Both place attachment and social interaction are considered to be separate concepts from participation and are often used to explain why different levels of participation exist in a given community $[1,11,25]$.

\subsection{Physical Environment and Place Relationship}

A growing body of research has investigated the connections between the physical environment and the three main dimensions of place relationship that comprise the focus of this study. These connections will be reviewed separately in the following paragraphs.

\subsubsection{Physical Environment and Place Attachment}

Most of the research concerning features of the physical environment and place attachment has been conducted at the neighborhood scale, followed by the home, city, and much less often, national regions [6,7]. At the neighborhood level, the features most often found to influence place attachment include the following: lack of noise [26,27], presence of quality green spaces (e.g., parks, playgrounds, street landscaping) [2,13,28,29], attractiveness of buildings [29,30], and lack of incivilities (e.g., graffiti, litter, lack of upkeep, feelings of insecurity, crime) [13,29].

\subsubsection{Physical Environment and Social Interaction}

There is a growing recognition in community sociology and psychology that the physical environment plays an important role in social interaction [6,9]. Regarding features of the built environment, urban planners, architects, environmental psychologists, and public health researchers have also contributed to this recent work. These researchers have concentrated on the relationship between neighborhood design and social interaction. Of particular interest are the benefits provided by traditional community or New Urbanist layouts as compared with typical contemporary suburban layouts. These studies have revealed that traditional community layouts provide more opportunities for social interaction by being more walkable (e.g., sidewalks, traffic-calming devices, street landscaping, lack of litter or graffiti) $[28,31]$ and offering enhanced access to commercial districts and public green spaces $[28,32,33]$. A handful of studies have investigated features of the built environment at the smaller site scale. These studies have revealed that social interaction can be enhanced through the presence of outdoor courtyards [34], common gardens [35], and trees and grass [36,37] in apartment complexes and public housing communities, and also front porches and narrow setbacks in traditional community layouts $[28,38,39]$. 


\subsubsection{Physical Environment and Community Participation}

Research concerning factors that enhance community participation has concentrated on individual characteristics, such as socioeconomic and demographic variables, or social networks and shared norms $[10,40,41]$. Of the handful of studies examining the connections between community participation and features of the built environment, most have been conducted at the neighborhood scale. Participation can be encouraged by attractive, walkable, safe neighborhoods where opportunities to socialize are supported by the provision of meeting places (e.g., local shops, eating places, parks) [10-12].

\subsection{Research Objectives}

Under these circumstances, the study tried to explore impact of outdoor physical environment onto place relationship of residents. First, the relationship was explored through an integrated view of environmental planning. Then, impacts of essential elements from outdoor environment to place relationship were examined.

\section{Methods}

\subsection{Procedure of Analyses Which Coping with the Study Goals}

To achieve the research goal, the study first identified the underlying of the two main constructs of the study, "place relationship" and "community planning features" with exploratory factor analysis, followed by canonical correlation analysis to determine the relationship between planning features and place relationship. Then, multiple regression analysis was conducted to pinpoint how planning features, including predictors and their strength, impact place relationship.

Canonical correlation analysis was utilized to explore the structure of the relationships between multiple independent and dependent variables. This is the most powerful statistical technique available to investigate the structure of one or more relationships between sets of independent and dependent variables, through the estimation of one or more canonical functions. In studies involving complex human perceptions and beliefs where multiple variables represent a concept, this ability is invaluable [42]. Canonical correlation, additionally, reduces the probability of committing a Type 1 statistical error (i.e., the likelihood of concluding that a statistically significant relationship exists when it really does not) compared with a series of regression equations, namely one for each dependent variable [42].

Multiple regression analysis was conducted to help interpret the findings of the canonical correlation analyses. Each of the three place relationship dimensions were used separately as the dependent variable (predictand) with the four community planning feature factors of the final model used as the independent variables (predictors). Because gender, age, level of education, family composition, and length of residence have been shown to be related to these three dimensions, these five socio-demographic variables were accounted for in each of the multiple regression models.

\subsection{Sampling}

According to the sampling principle [43], the study adopted $95 \%$ confidential interval, $5 \%$ allowed error, and the total sample size should be greater than 278. In order to compare the impact of different community layouts toward place relationships, the study divided the total samples into three layout groups, i.e., alley, cluster, and large courtyard. In Taiwan, these three community layouts are the most popular in public housing. After the community types are set, target communities for sampling could also be decided accordingly. The researchers chose three military dependent communities in Tainan, since this type of community is representative of public housing of Taiwan, and the demographic characteristics of the residents are homogeneous. The sample size of each community surveyed was determined according to the proportion of the population in each community to the total population of the three communities. 
A total of 299 valid samples were collected out of the 4600 total residents (6.5\%) from the three public housing communities surveyed through stratified quota sampling, to ensure that the sample described the profile of the overall population of these communities. Participants had to be at least 15 years of age or older to participate. Interviews were conducted with older-aged residents who had poor eyesight and difficulty reading the written survey. Of the participants, $60.2 \%$ were female, $50.2 \%$ were 51 years of age or older, $28.1 \%$ had a college or graduate degree, $56.2 \%$ were members of a nuclear family, and $52.2 \%$ had lived in their current residence for 10 years or less (Table 1). Comparing the three communities, no significant differences were found concerning the gender, age, and family composition of the participants. However, the participants of the cluster were slightly better educated and those of the older alley had substantially longer length of residence (Table 2).

Table 1. Summary of the participant demographics $(N=299)$.

\begin{tabular}{ccc}
\hline Variables & Number & Percentage \\
\hline Gender & 180 & \\
Female & 119 & 60.2 \\
Male & & 39.8 \\
\hline Age (years) & 17 & 5.7 \\
$15-20$ & 34 & 11.3 \\
$21-30$ & 43 & 14.4 \\
$31-40$ & 55 & 18.4 \\
$41-50$ & 150 & 50.2 \\
51+ & 110 & \\
Level of Education & 105 & 36.8 \\
Less than high school & 78 & 35.1 \\
High school diploma & 6 & 26.1 \\
College degree & & 2.0 \\
Graduate degree & 71 & \\
\hline Family Composition & 168 & 23.7 \\
Unmarried & 60 & 56.2 \\
Nuclear & & 20.1 \\
Extended & 156 & 52.2 \\
(multigenerational) & & \\
\hline Length of Residence (years) & &
\end{tabular}

Table 2. Demographic differences among the three communities.

\begin{tabular}{|c|c|c|c|c|}
\hline & $\begin{array}{l}\text { Dong-Men (1986) } \\
\text { Alley }(n=126)\end{array}$ & $\begin{array}{l}\text { Guo-Mao (1997) } \\
\text { Cluster }(n=62)\end{array}$ & $\begin{array}{c}\text { Da-Dao (2003) } \\
\text { Large Courtyard } \\
(n=111)\end{array}$ & $\begin{array}{l}\text { ANOVA or } \\
\text { Crosstabs } \\
\text { Analysis }\end{array}$ \\
\hline Gender (\% female) & $68.0^{\mathrm{a}}$ & $52.4^{\mathrm{a}}$ & $55.4^{\mathrm{a}}$ & $\mathrm{F}=2.99$ \\
\hline Age (years) & $49.0^{\mathrm{a}}$ & $49.4^{\mathrm{a}}$ & $45.4^{\mathrm{a}}$ & $\mathrm{F}=2.53$ \\
\hline Level of Education (years) & $11.9^{\mathrm{a}}$ & $13.6^{\mathrm{b}}$ & $12.4^{\mathrm{a}}$ & $\mathrm{F}=10.3^{* * *}$ \\
\hline Family Composition (\%) & 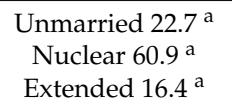 & $\begin{array}{c}\text { Unmarried } 15.9^{\mathrm{a}} \\
\text { Nuclear } 63.5^{\mathrm{a}} \\
\text { Extended } 20.6^{\mathrm{a}}\end{array}$ & $\begin{array}{c}\text { Unmarried } 29.6^{\mathrm{a}} \\
\text { Nuclear } 46.4^{\mathrm{a}} \\
\text { Extended } 24.1^{\mathrm{a}}\end{array}$ & $\chi^{2}=8.0$ \\
\hline Length of Residence (years) & $18.1^{\mathrm{a}}$ & $7.7^{\mathrm{b}}$ & $6.1^{\mathrm{b}}$ & $\mathrm{F}=115.2 * * *$ \\
\hline
\end{tabular}

\subsection{Study Sites}

This study examined three public housing communities located in the city of Tainan, which is in southwestern coastal region of the country of Taiwan. These communities, named Dong-Men, Guo-Mao, and Da-Dao, were chosen for the following reasons. First, they are representative of the three 
types of public housing arrangements that are commonly used in Taiwan. These arrangements will be referred to as the alley, cluster, and large courtyard, respectively. In the alley layout, the residential community is divided by public streets that run through the community (Figures 2 and 3). In the cluster layout, the residential buildings are grouped with the objective of creating more open areas for recreation and social interaction. Because these open areas are not completely surrounded by residential buildings, compared with the large courtyard layout, described next, these areas are less closed and more open for use by residents of the nearby neighborhood (Figures 4 and 5). In the large courtyard, the residential buildings are located on the perimeter of the community. This building layout results in a single, large, closed central open area (Figures 6 and 7).

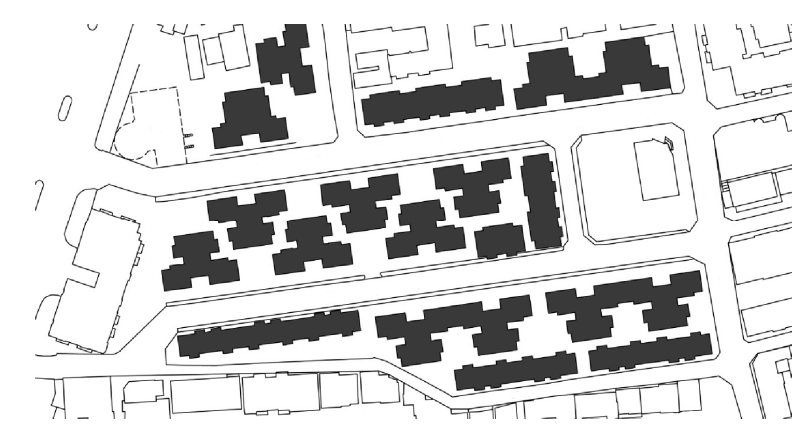

Figure 2. Alley layout that features public roads dividing the community (Dong-Men housing community built in 1986). Residential density: $11,275 \mathrm{p} / \mathrm{km}^{2}$.
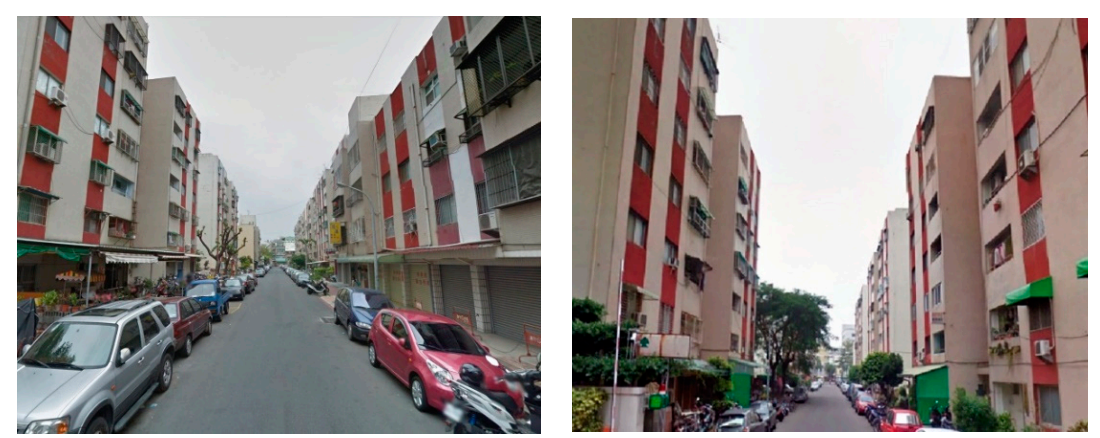

Figure 3. Photographs of roads that run through the alley layout.

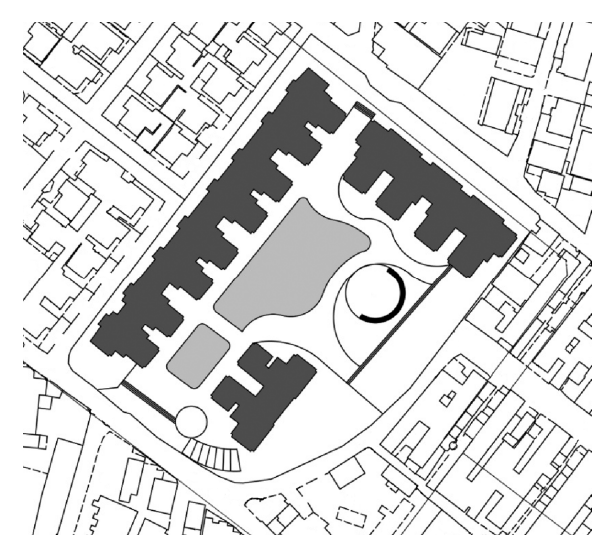

Figure 4. Cluster layout where the buildings are grouped to provide larger open areas (Guo-Mao housing community built in 1997). Residential density: 6756 p/ km². 

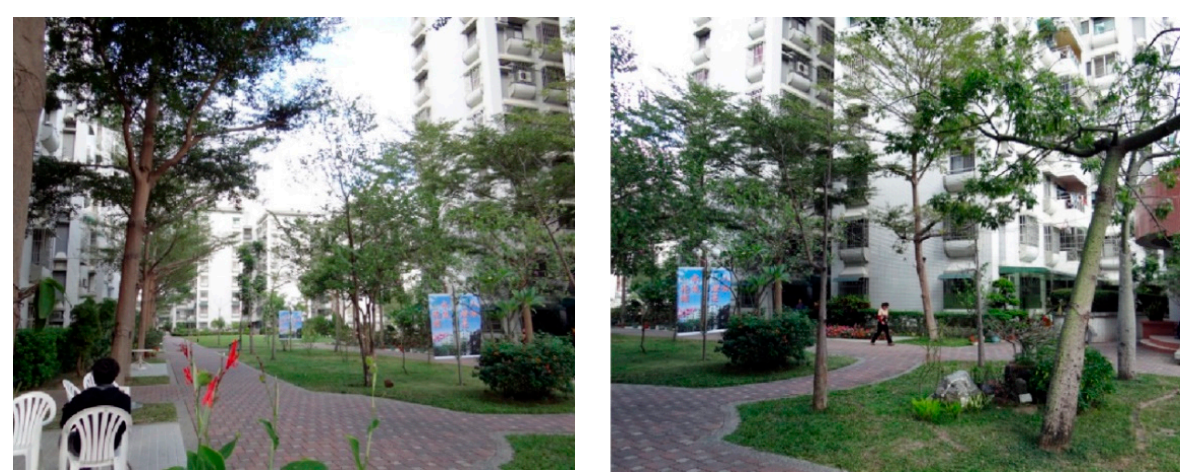

Figure 5. Photographs of the open areas of the cluster layout.

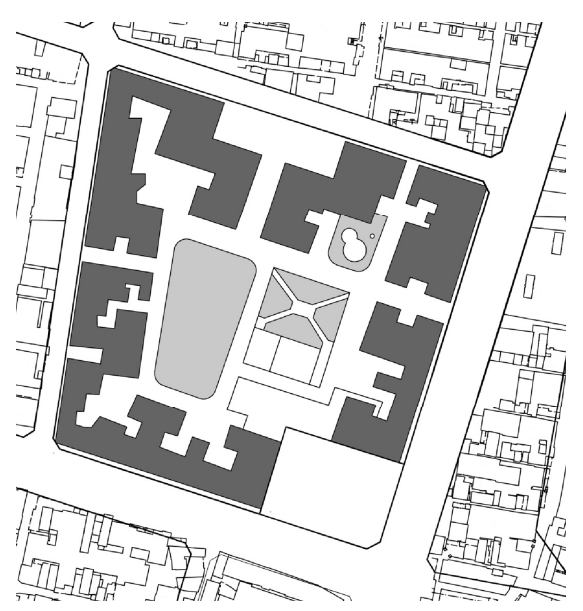

Figure 6. Large courtyard layout that features a single, large, central open area (Da-Dao housing community built in 2003). Residential density: 7601 p/ $\mathrm{km}^{2}$.
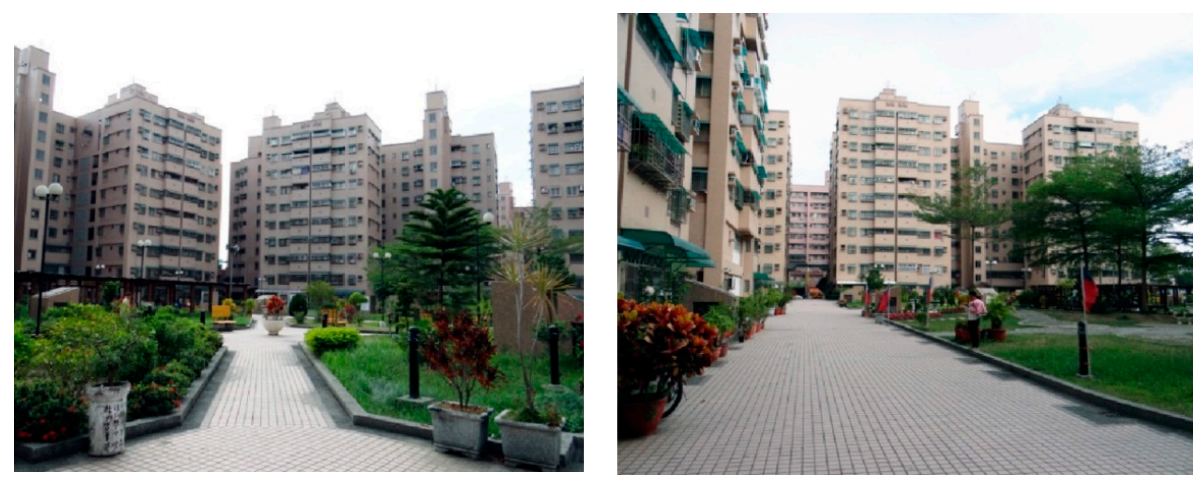

Figure 7. Photographs of the central open area of the large courtyard layout.

Second, these communities are representative of the average-sized Taiwanese public housing community in terms of number of inhabitants. The populations of the Dong-Men, Guo-Mao, and Da-Dao communities were 1950, 850, and 1800 residents, respectively.

Third, all three communities were built within roughly the same period of time, from 1986 to 2003. Lastly, these communities were chosen to increase the similarities in the demographic characteristics of the residents surveyed, including gender, age, level of education, family composition, and length of residence. These three public housing communities shared identical eligibility requirements. Past studies have revealed that these factors are associated with differences in 
residents' satisfaction with their physical environment $[2,44,45]$ and all three place relationship dimensions-place attachment $[6,13,46]$, social interaction [45,47], and community participation $[11,48]$. Homeownership has also been linked with the three place relationship dimensions, particularly place attachment $[6,8,49]$ and community participation $[8,10]$. In these three communities, the percentage of homeownership was above 95\%, similar to that of public housing in Taiwan as a whole [50].

\subsection{Measures}

\subsubsection{Community Planning Features}

Resident satisfaction with the outdoor community planning features was measured with a questionnaire composed of 20 items concerning residents' perceptions of their environment. Research concerning the connections between the three place relationship dimensions and the physical environment, as noted above, has been conducted at scales other than the site scale. As a result, the items used in this study were derived from research investigating the issues of residential satisfaction and residential quality [51]. Four items are specific to the concerns of architects and landscape architects in designing outdoor environments that will satisfy the needs of the users. These included questions concerning the width and paving material of the community walkways (Items 5 and 8), and shelter from the weather and outdoor seating (Items 13 and 14) [52,53]. Two items involved issues perhaps unique to Taiwan. Item 7 explored the community's nighttime environment (Table 3). Due to the country's tropical and subtropical climate, the outdoor social spaces are primarily used in late afternoon or after sunset. In addition, no items concerning the upkeep of community site features were used. The concept of maintenance with regard to the built environment is not a part of the local culture. The items will be measured using the 5-point Likert scale, and be rated by the residents on a scale ranging from $1=$ very dissatisfied to $5=$ very satisfied.

Table 3. Factors and factor loadings for exploratory factor analysis of community planning feature for outdoor spaces.

\begin{tabular}{|c|c|c|c|c|}
\hline How Satisfied Are You with the: & $\begin{array}{l}1 . \\
\text { Outdoor } \\
\text { Space } \\
\text { Quality }\end{array}$ & $\begin{array}{l}2 . \\
\text { Circulation } \\
\text { Planning }\end{array}$ & $\begin{array}{c}. \\
\text { Outdoor } \\
\text { Recreational } \\
\text { Facilities }\end{array}$ & $\begin{array}{c}4 . \\
\text { Community } \\
\text { Layout and } \\
\text { Administration }\end{array}$ \\
\hline $\begin{array}{l}\text { 1. Outdoor air circulation in } \\
\text { this community? }\end{array}$ & 0.71 & & & \\
\hline $\begin{array}{l}\text { 2. Amount of open space in } \\
\text { this community? }\end{array}$ & 0.67 & & & \\
\hline $\begin{array}{l}\text { 3. Connections with all parts of the } \\
\text { community provided by the } \\
\text { outdoor walkways? }\end{array}$ & 0.67 & & & \\
\hline $\begin{array}{l}\text { 4. Access to sunlight in the outdoor } \\
\text { environment of this community? }\end{array}$ & 0.64 & & & \\
\hline $\begin{array}{l}\text { 5. Widths of the outdoor walkways in } \\
\text { this community? }\end{array}$ & 0.63 & & & \\
\hline $\begin{array}{l}\text { 6. Accessibility of the routes provided by } \\
\text { the outdoor walkways in this } \\
\text { community? }^{\text {a }}\end{array}$ & 0.62 & & & \\
\hline $\begin{array}{l}\text { 7. Nighttime environment of } \\
\text { this community? }\end{array}$ & 0.59 & & & \\
\hline
\end{tabular}


Table 3. Cont.

\begin{tabular}{|c|c|c|c|c|}
\hline How Satisfied Are You with the: & $\begin{array}{c}1 . \\
\text { Outdoor } \\
\text { Space } \\
\text { Quality }\end{array}$ & $\begin{array}{c}2 . \\
\text { Circulation } \\
\text { Planning }\end{array}$ & $\begin{array}{c}. \\
\text { Outdoor } \\
\text { Recreational } \\
\text { Facilities }\end{array}$ & $\begin{array}{c}4 . \\
\text { Community } \\
\text { Layout and } \\
\text { Administration }\end{array}$ \\
\hline $\begin{array}{l}\text { 8. Quality of the paving used for the } \\
\text { outdoor walkways in this community? }\end{array}$ & 0.59 & & & \\
\hline $\begin{array}{l}\text { 9. Amount of green space in } \\
\text { this community? }\end{array}$ & 0.56 & & & \\
\hline $\begin{array}{l}\text { 10. Separation between vehicles and } \\
\text { pedestrians in this community? }\end{array}$ & & 0.90 & & \\
\hline $\begin{array}{l}\text { 11. Accessibility and availability of the } \\
\text { vehicular parking spaces in } \\
\text { this community? }\end{array}$ & & 0.86 & & \\
\hline $\begin{array}{l}\text { 12. Connections between the residential } \\
\text { buildings and the nearby neighborhood? }\end{array}$ & & 0.54 & & \\
\hline $\begin{array}{l}\text { 13. Outdoor provisions that shelter users } \\
\text { from the sun, rain, and wind in } \\
\text { this community? }\end{array}$ & & & 0.79 & \\
\hline 14. Outdoor seating in this community? & & & 0.78 & \\
\hline $\begin{array}{l}\text { 15. Outdoor areas designed for social } \\
\text { interaction in this community? }\end{array}$ & & & 0.65 & \\
\hline $\begin{array}{l}\text { 16. Safety in the outdoor areas of } \\
\text { this community? }\end{array}$ & & & & 0.77 \\
\hline $\begin{array}{l}\text { 17. Access to the main entrance of this } \\
\text { community from your } \\
\text { particular dwelling? }\end{array}$ & & & & 0.77 \\
\hline 18. Location of the play areas? & & & & 0.66 \\
\hline $\begin{array}{l}\text { Cronbach's } \alpha \\
\text { \% Variance Explained } \\
\text { \%Total Variance Explained }\end{array}$ & $\begin{array}{l}0.88 \\
22.61 \\
62.71\end{array}$ & $\begin{array}{c}0.79 \\
13.57\end{array}$ & $\begin{array}{c}0.73 \\
13.52\end{array}$ & $\begin{array}{c}0.73 \\
13.00\end{array}$ \\
\hline
\end{tabular}

Only factor loadings $>0.40$ are shown. Extraction method: Principal Component Analysis. Rotation method: Varimax with Kaiser Normalization. ${ }^{\text {a }}$ Item in its entirety-Accessibility of the routes provided by the outdoor walkways in this community, involving such factors as level.

\subsubsection{Place Relationship}

Place relationship was measured with a questionnaire composed of 16 items. Items 1 to 7 examined the issues of place identity and place dependence $[13,20,54]$. Items 8 to 11 investigated community social interaction [55,56]. Lastly, Items 12 and 13 explored community participation and neighborhood cohesion $[55,57,58]$. The items will be also measured using the 5-point Likert scale, and be rated by the residents on a scale ranging from $1=$ completely disagree to $5=$ completely agree. 


\section{Results}

\subsection{Exploratory Factor Analysis}

Exploratory factor analysis was conducted to extract the factors that were used as the independent and dependent variables in the canonical correlation analysis. Concerning the community planning features questionnaire, 18 of the 20 items were clustered into four extracted factors (Table 3). Two items were removed from the final model, "How satisfied are you with the amount of noise in this community?" and "How satisfied are you with the landscape design of this community?" due to low factor loading $(<0.30)$ and high double loading $(>0.50)$ respectively. These factors were labeled and described as follows:

- “Outdoor Space Quality"—residents' satisfaction with specific community planning features and characteristics of the overall outdoor environment

- "Circulation planning"-residents' satisfaction with convenient access to the outdoor environment, their vehicles, and the surrounding neighborhood

- "Outdoor recreational facilities" — residents' satisfaction with outdoor facilities that encourage them to stay outside and socialize

- "Community layout and administration" - residents' satisfaction with the overall outdoor layout and security in the community

Regarding place relationship, the items loaded as expected onto three extracted factors corresponding to the three place relationship subdimensions investigated in this study (Table 4). Three items were removed from the final model. The item "This community is similar to the one that I grew up in" had low factor loading $(<0.35)$, "I would like to stay in this community" double loaded (>0.50), and "I have lived in a similar community" was removed to increase the reliability of the extracted factor, social interaction. These factors were labeled and described as "place attachment", "social interaction", and "community participation".

Table 4. Factors and factor loadings for exploratory factor analysis of place relationship items.

\begin{tabular}{|c|c|c|c|c|}
\hline & & $\begin{array}{c}1 . \\
\text { Place } \\
\text { Attachment }\end{array}$ & $\begin{array}{c}2 . \\
\text { Social } \\
\text { Interaction }\end{array}$ & $\begin{array}{c}3 . \\
\text { Community } \\
\text { Participation }\end{array}$ \\
\hline 1. & I like living in this community & 0.80 & & \\
\hline 2. & I feel very comfortable living in this community & 0.79 & & \\
\hline 3. & This community feels like home & 0.78 & & \\
\hline 4. & No other community can substitute for this one & 0.77 & & \\
\hline 5. & This community is better than other communities & 0.77 & & \\
\hline 6. & This community is very important to me & 0.76 & & \\
\hline 7. & I do not wish to leave this community & 0.63 & & \\
\hline 8. & I know many of my neighbors in this community & & 0.83 & \\
\hline 9. & I have a lot of friends in this community & & 0.75 & \\
\hline 10. & I like to socialize with my neighbors & & 0.70 & \\
\hline 11. & I feel that I belong to this community & & 0.62 & \\
\hline 12. & $\begin{array}{l}\text { I participate in maintaining and managing } \\
\text { community facilities }\end{array}$ & & & 0.86 \\
\hline 13. & I often participate in community activities & & & 0.81 \\
\hline \multicolumn{2}{|c|}{ Cronbach's $\alpha$} & 0.91 & 0.80 & 0.65 \\
\hline \multicolumn{2}{|c|}{ \% Variance Explained } & 33.77 & 20.91 & 12.43 \\
\hline \multicolumn{2}{|c|}{ \% Total Variance Explained } & 67.11 & & \\
\hline
\end{tabular}

Only factor loadings $>0.40$ are shown. Extraction method: Principal Component Analysis. Rotation method: Varimax with Kaiser Normalization.

\subsection{Canonical Correlation Analysis}

The canonical correlation analysis revealed that significant associations existed between the community planning factors being investigated and place relationship. These associations involved three of the four community planning factors, specifically outdoor space quality, circulation planning, community layout, and all three extracted place relationship factors (Figures 8 and 9). 


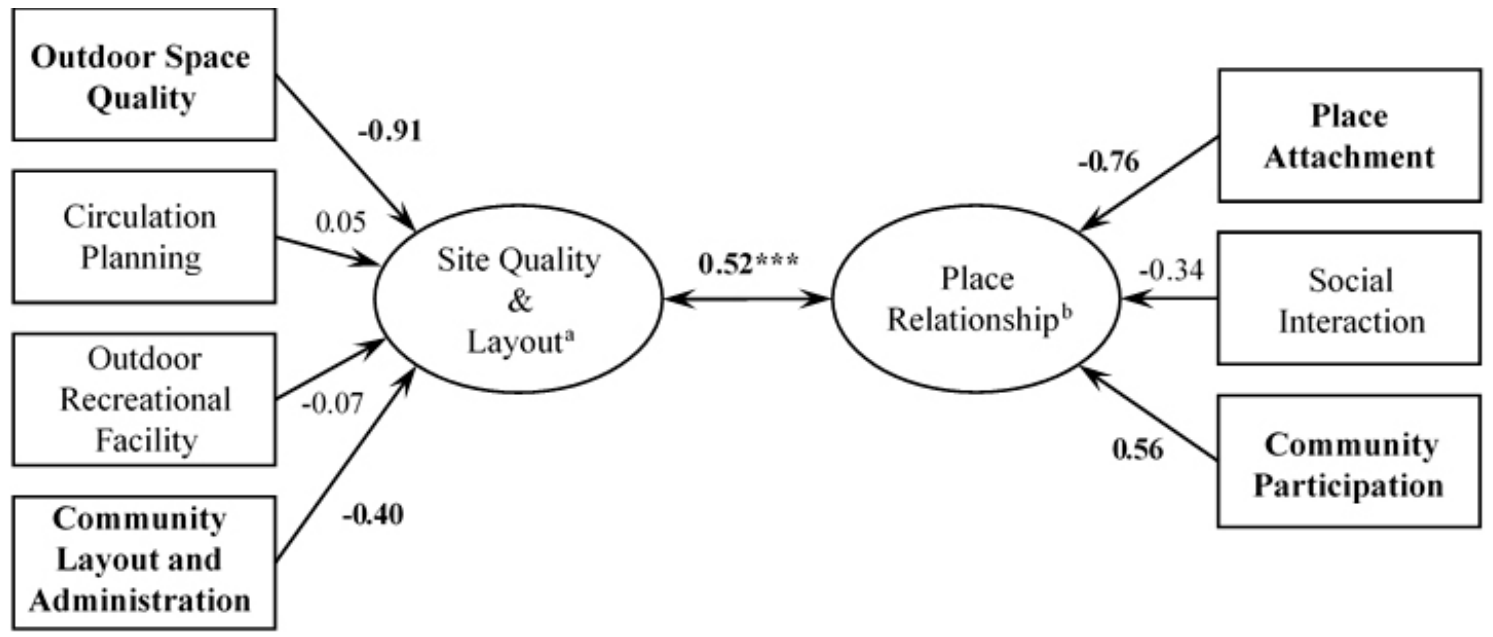

Figure 8. First canonical function with the significant relationships highlighted (bold font style). Lower levels of satisfaction with both outdoor space quality and community layout were linked with lower place attachment, but greater community participation. ${ }^{a}$ First canonical variate $X ;{ }^{b}$ First canonical variate $\mathrm{Y}^{* * *}=p<0.001$.

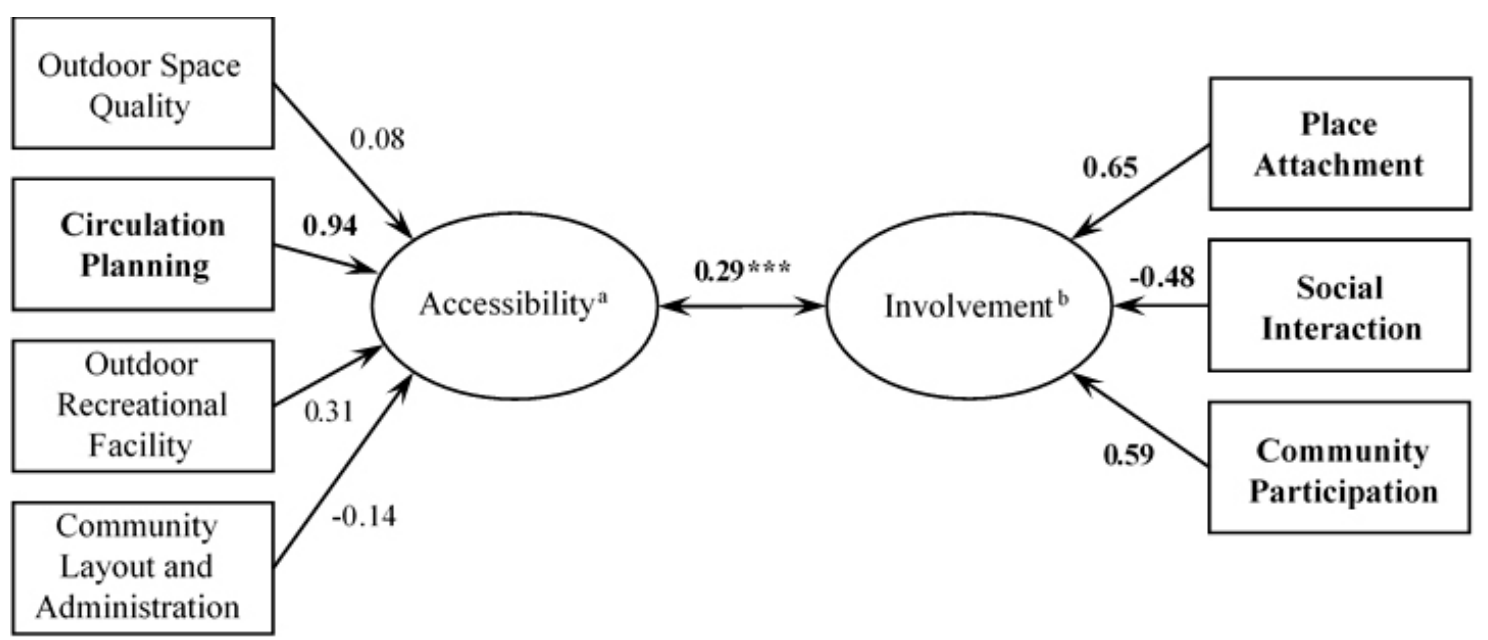

Figure 9. Second canonical function with the significant relationships highlighted (bold font style). Higher levels of satisfaction with circulation planning were associated with greater place attachment and community participation, but less social interaction. ${ }^{a}$ Second canonical variate $\mathrm{X} ;{ }^{\mathrm{b}}$ Second canonical variate $\mathrm{Y}^{* * *}=p<0.001$.

Two statistically significant canonical functions were found $(F=10.52$, Wilks's lambda $=0.67$, $p<0.001$ ), each function representing a different relationship between the community planning factor and place relationship sets of factors (Figures 8 and 9). A minimum loading level of 0.40 will be used to indicate relationships of substantive importance. The total variance of the dependent variables explained by the canonical variates of the two canonical functions was $11.54 \%$. The value of this variance is analogous to the $R^{2}$ statistic of multiple regression, and the meaning as an index is similar [42].

The relationship between the first pair of canonical variates (Figure 8) will be described with positive terminology to avoid the confusion of describing a connection between two negative values (i.e., negative values of the independent or dependent variables and the corresponding canonical variates will be changed to positive and vice versa). This relationship revealed that greater levels of satisfaction with the outdoor space quality (0.91) and community layout $(0.40)$ were linked with 
higher levels of place attachment (0.76) and lower perceived levels of community participation $(-0.56)$. The first canonical variate $X$ explained $8.88 \%$ of the variance in the dependent variables.

The relationship between the second pair of canonical variates (Figure 9) can be expressed as follows: Greater satisfaction with circulation planning (0.94) was associated with both higher levels of place attachment (0.65) and community participation (0.59), but lower levels of social interaction $(-0.48)$. The second canonical variate $\mathrm{X}$ explained $2.66 \%$ of the variance in the dependent variables.

\subsection{Multiple Regression Analysis}

The five socio-demographic control variables were not consistently predictive of the three place relationship dimensions in the three communities (Tables 5-7). Although past studies have found links between these variables and dimensions, the fact that reliable connections were not found is not too surprising. In the existing literature, one of the most consistent positive socio-demographic predictor of place attachment and social interaction is length of residence [6,8], and of community participation is education level $[11,59]$. Nevertheless, not all studies have found a significant relationship between these predictors and their respective place relationship dimensions $[1,6,60]$. Researchers have suggested that the erratic patterns of relationships between these socio-demographic variables and place relationship dimensions may be due to extraneous physical or social environmental factors $[1,6,61]$.

Table 5. Place attachment affected by community planning factors, in which total samples, alley, cluster, and large courtyard regressed separately by the four community planning factors.

\begin{tabular}{|c|c|c|c|c|c|c|c|c|}
\hline \multirow[t]{2}{*}{ Predictor } & \multicolumn{2}{|c|}{ Total } & \multicolumn{2}{|c|}{$\begin{array}{c}\text { Alley } \\
\text { (Dong-Men 1986) }\end{array}$} & \multicolumn{2}{|c|}{$\begin{array}{c}\text { Cluster } \\
\text { (Guo-Mao 1997) }\end{array}$} & \multicolumn{2}{|c|}{$\begin{array}{c}\text { Large Courtyard } \\
\text { (Da-Dao 2003) }\end{array}$} \\
\hline & $\Delta \mathbf{R}^{2}$ & $\beta$ & $\Delta \mathbf{R}^{2}$ & $\beta$ & $\Delta \mathbf{R}^{2}$ & $\beta$ & $\Delta \mathbf{R}^{2}$ & $\beta$ \\
\hline \multicolumn{9}{|l|}{ Control variables } \\
\hline \multicolumn{9}{|l|}{ Gender } \\
\hline Age & & & & & & & $0.08^{* *}$ & $0.24 * *$ \\
\hline \multicolumn{9}{|l|}{ Level of education } \\
\hline Family composition & & & & & $0.04 *$ & $0.23 *$ & & \\
\hline Length of residence & $0.03 * *$ & $0.19 * *$ & & & $0.09 * *$ & $0.32 * *$ & & \\
\hline Community planning factors & 0.17 & & 0.10 & & 0.47 & & 0.30 & \\
\hline Outdoor space quality & $0.14^{* * *}$ & $0.35^{* * *}$ & & & $0.35^{* * *}$ & $0.83^{* * *}$ & $0.05^{* *}$ & $0.23 * *$ \\
\hline Circulation planning & $0.02 * *$ & $0.20^{* * *}$ & $0.04 *$ & $-0.19 *$ & & & $0.03 *$ & 0.21 * \\
\hline Outdoor recreational facilities & $0.01 *$ & $0.12^{*}$ & $0.06 * *$ & $0.25 * *$ & $0.05 *$ & $0.22 *$ & & \\
\hline $\begin{array}{l}\text { Community layout and } \\
\text { administration }\end{array}$ & & & & & $0.07 * *$ & $0.25^{* * *}$ & $0.22 * * *$ & $0.27 * *$ \\
\hline Total $R^{2}$ & \multicolumn{2}{|c|}{$0.20^{* * *}$} & \multicolumn{2}{|c|}{$0.10 * *$} & \multicolumn{2}{|c|}{$0.60 * * *$} & \multicolumn{2}{|c|}{$0.38^{* * *}$} \\
\hline$n$ & \multicolumn{2}{|c|}{299} & \multicolumn{2}{|c|}{126} & \multicolumn{2}{|c|}{62} & \multicolumn{2}{|c|}{111} \\
\hline
\end{tabular}

${ }^{*} p<0.05 ;{ }^{* *} p<0.01 ;{ }^{* * *} p<0.001$. 
Table 6. Social interaction affected by community planning factors, in which total samples, alley, cluster, and large courtyard regressed separately by the four community planning factors.

\begin{tabular}{|c|c|c|c|c|c|c|c|c|}
\hline \multirow[t]{2}{*}{ Predictor } & \multicolumn{2}{|c|}{ Total } & \multicolumn{2}{|c|}{$\begin{array}{c}\text { Alley } \\
\text { (Dong-Men 1986) }\end{array}$} & \multicolumn{2}{|c|}{$\begin{array}{c}\text { Cluster } \\
\text { (Guo-Mao 1997) }\end{array}$} & \multicolumn{2}{|c|}{$\begin{array}{c}\text { Large Courtyard } \\
\text { (Da-Dao 2003) }\end{array}$} \\
\hline & $\Delta R^{2}$ & $\beta$ & $\Delta R^{2}$ & $\beta$ & $\Delta R^{2}$ & $\beta$ & $\Delta R^{2}$ & $\beta$ \\
\hline $\begin{array}{l}\text { Control variables } \\
\text { Gender } \\
\text { Age } \\
\text { Level of education } \\
\text { Family composition } \\
\text { Length of residence }\end{array}$ & $\begin{array}{c}0.10^{* * *} \\
0.01^{*} \\
0.03^{* *}\end{array}$ & $\begin{array}{c}0.20^{* *} \\
-0.13^{*} \\
0.16^{*}\end{array}$ & $0.03^{*}$ & -0.19 * & $0.15^{* *}$ & 0.40 * & $0.28^{* * *}$ & $0.45^{* * *}$ \\
\hline $\begin{array}{l}\text { Community planning factors } \\
\text { Outdoor space quality } \\
\text { Circulation planning } \\
\text { Outdoor recreational facilities } \\
\text { Community layout and } \\
\text { administration }\end{array}$ & - & & $\begin{array}{c}- \\
0.06^{* *}\end{array}$ & $0.19 *$ & - & & - & \\
\hline $\begin{array}{l}\text { Total } R^{2} \\
n\end{array}$ & & & & & & & & \\
\hline
\end{tabular}

Table 7. Community participation affected by community planning factors, in which total samples, alley, cluster, and large courtyard regressed separately by the four community planning factors.

\begin{tabular}{|c|c|c|c|c|c|c|c|c|}
\hline \multirow[t]{2}{*}{ Predictor } & \multicolumn{2}{|c|}{ Total } & \multicolumn{2}{|c|}{$\begin{array}{c}\text { Alley } \\
\text { (Dong-Men 1986) }\end{array}$} & \multicolumn{2}{|c|}{$\begin{array}{c}\text { Cluster } \\
\text { (Guo-Mao 1997) }\end{array}$} & \multicolumn{2}{|c|}{$\begin{array}{l}\text { Large Courtyard } \\
\text { (Da-Dao 2003) }\end{array}$} \\
\hline & $\Delta R^{2}$ & $\beta$ & $\Delta R^{2}$ & $\beta$ & $\Delta R^{2}$ & $\beta$ & $\Delta R^{2}$ & $\beta$ \\
\hline $\begin{array}{l}\text { Control variables } \\
\text { Gender } \\
\text { Age } \\
\text { Level of education } \\
\text { Family composition } \\
\text { Length of residence }\end{array}$ & $0.02 * *$ & $0.16^{* *}$ & & & $0.07 *$ & $0.27 *$ & $0.14^{* * *}$ & $0.38^{* * *}$ \\
\hline Community planning factors & 0.12 & & 0.22 & & 0.20 & & - & \\
\hline Outdoor space quality & $0.07^{* * *}$ & $\begin{array}{c}-0.28 \\
* * * \\
0.17 * *\end{array}$ & $0.18^{* * *}$ & $\begin{array}{l}-0.39 \\
* * *\end{array}$ & & & & \\
\hline Outdoor recreational facilities & & & & & $0.11^{* *}$ & $\underset{* *}{-0.34}$ & & \\
\hline $\begin{array}{l}\text { Community layout and } \\
\text { administration }\end{array}$ & $0.02 *$ & -0.13 * & $0.04 *$ & $-0.21 *$ & $0.09 *$ & $0.32 * *$ & & \\
\hline $\begin{array}{l}\text { Total } R^{2} \\
n\end{array}$ & $\begin{array}{l}0.14^{* * *} \\
299\end{array}$ & & $\begin{array}{l}0.22 * \\
126\end{array}$ & & $\begin{array}{c}0.27^{* * *} \\
62\end{array}$ & & $\begin{array}{c}0.14^{* * *} \\
111\end{array}$ & \\
\hline
\end{tabular}

Of the three place relationship dimensions, the community planning factors were most strongly predictive of place attachment. These planning factors explained $17 \%$ of the variance of all the communities considered together, and $10 \%, 47 \%$, and $30 \%$ of the variances for the alley, cluster, and large courtyard layouts, respectively (Table 5). The "outdoor space quality" as well as "community layout and administration" factors were strong positive predictors of place attachment for both the cluster and large courtyard, but not for the alley.

The community planning factors were also predictive of community participation, explaining $12 \%$ of the variance of all the communities considered together. These planning factors also explained $22 \%$ and $20 \%$ of the variances for the alley and cluster, but were not predictive of community participation in the large courtyard (Table 7). 
Finally, the community planning factors were poorly predictive of social interaction. They explained $6 \%$ of the variance for the alley, but were not predictive of social interaction in the other two layouts (Table 6).

\section{Discussion}

The results of this study revealed that significant connections existed between community planning features and all three place relationship dimensions. These small-scale site features have not been extensively investigated in the past with regard to these dimensions. In addition, a given community planning factor can be simultaneously related in different ways to these dimensions. Most importantly, greater satisfaction with the outdoor space quality as well as community layout was found to be positively associated with higher levels of place attachment and lower levels of community participation in community affairs (Figure 8). In addition, circulation planning was found to be positively linked with higher levels of both place attachment and community participation, and lower levels of social interaction (Figure 9).

\subsection{Four Community Planning Factors}

The findings of the exploratory factor analysis revealed that the community planning feature items investigated in this study can be grouped into four factors: "outdoor space quality", "circulation planning", "outdoor recreational facilities", and "community layout and administration" (Table 3). These factors were assorted based on similarity among participants' recognition toward the environmental factors they encountered. After factor analysis, similar items will accumulate themselves to form several factors which underlie the construct tested. The underlying of the construct may vary due to different cognition of the survey participants. That indicates the residents of public housing in Taiwan find that "outdoor space quality", "circulation planning", "outdoor recreational facilities", and "community layout and administration" are the most significant planning factors for the public housing. Among which, "outdoor recreational facilities" is worth noting considering its appeal in Taiwan given the amount of rain and sunshine in the subtropical climate. The policymakers and designers of public housing and similar communities should be made aware that these four factors were linked at different strengths with diverse effects on the inhabitants of these sites. For example, policymakers with limited funding who wish to solely enhance feelings of place attachment might concentrate first on improving the outdoor space quality and secondly the community layout of a residential housing community (Figure 8). To increase levels of both place attachment and community participation, one might first upgrade the circulation planning of a site (Figure 9).

\subsection{The Canonical Functions betwwen Planning Factors and Place Relationships}

The first canonical function reveals that greater satisfaction with outdoor space quality and community layout can enhance residents' feelings of place attachment and social interaction while at the same time discouraging community participation (Figure 8). Past research conducted at the neighborhood scale supports these findings. For example, positive perceptions of the physical environment of neighborhoods have been found to be related to greater place attachment $[2,13]$. In addition, high quality outdoor spaces and good community administration restraint residents toward community participation. In other words, perceived neighborhood problems that included planning factors of the physical environment have been shown to motivate residents into collective action $[10,62,63]$. In sum, the first canonical function suggests that outdoor space quality and community layout promote place relationships of the residents.

The second function shows that a given site planning factor can concurrently affect multiple place relationship dimensions in opposing ways (Figure 9). The strongest link in this function was positive between circulation planning and both place attachment and community participation, but negative to social interaction. According to this function, circulation planning affects place attachment strongly. Previous researches, as discussed in Section 1.1.1, suggested physical environment facilitates place 
attachment. This study further indicates that within general physical environment, circulation planning along with outdoor space quality and community layout of function1, are the planning factors which enhance place attachment. Almost as strong as the connection between circulation planning and community participation (Figure 9). Relatively few studies have investigated the role of the physical environment regarding participation. Nonetheless, at the neighborhood scale researchers have concluded that the presence of local, good quality services and amenities (e.g., stores, parks, community centers, recreation centers, green open spaces) are associated with greater social interaction and participation in local groups $[11,64]$. In addition, positive perceptions of the user-friendliness of the local walking environment was found by older adults to be related to higher levels of social interaction and community participation [65]. Circulation planning, therefore, may be important in helping the residents in this study to access such local facilities.

The negative relationship between circulation planning and social interaction (Figure 9) seems to be in contradiction to some studies $[30,34,35]$. Since community scales in Taiwan are relatively small, circulation and accessibility of the community imply more externally rather than internally. It could be that the better the circulation is planned, the fewer chances the residents get to encounter neighbors. As discussed above, research at the neighborhood scale has linked similar planning factors of accessibility with greater social interaction. Perhaps at the smaller scale of a specific site, features such as connections with the nearby neighborhood (Item 12) or the accessibility and availability of vehicular parking (Item 11) might encourage residents to interact more with people who live outside the community (Table 3).

\subsection{Different Community Layout Affect Place Relationships Differently}

Almost all of the past studies have concentrated on the connections between neighborhood or larger scale environmental characteristics and the three place relationship dimensions $[10,11,13]$. The findings of this study revealed that smaller scale community planning features were also significantly associated with these dimensions.

The multiple regression results suggest that the community planning factors affect place attachment the most (17\% variance explained), community participation ranks next $(12 \%$ variance explained), while social interaction is most influenced by personal characteristics, such as age, length of residence, and level of education. The relationships between community planning factors and the place relationship dimensions also differ among the three community layouts. The strengths and types of community planning factors that were predictive of place attachment and community participation varied greatly among the three community layouts (Tables 5 and 7). Among the three community layouts, communities with cluster layout are the most influenced by the planning factors ( $47 \%$ variance explained) onto their residents' place attachment. Communities with large courtyards follow as the second, in which $30 \%$ variance is explained by planning factors, while place attachment of communities with alley layout is only slightly affected by planning factors (10\% variance explained).

Policymakers and designers of housing communities have an obligation to be aware of the impact that these and other community planning factors and layouts can have on many aspects of residents' relationships with their communities. For example, if one wishes to increase residents' place attachment, one should consider not only improving the outdoor space quality and community layout factors, but also using the cluster rather than the alley or large courtyard (Figure 8 and Table 5). To decrease community participation resulting from dissatisfaction with the physical environment, one might focus again on improving the outdoor space quality and community layout factors and also not use the alley (Figure 8 and Table 7).

\subsection{Community Planning Features Are Powerful Affectors on Their Residents}

The amount of variance explained by the first canonical variate (i.e., $8.88 \%$ ) is comparable to the reported effects of both building and site scale landscape features on their users. For example, the size of retail stores and the presence or absence of skylights were found to explain $6.5 \%$ and 
$4.5 \%$ of the variance in sales respectively [66]. Studies of the effects of school buildings (e.g., lighting, noise, air quality, age of buildings) on student performance have reported that $3-6 \%$ of the variance in standardized test scores can be explained by such features $[67,68]$. Concerning the outdoor environment, natural features of high school campus landscapes were found to explained over $5 \%$ of the variance in such test scores [69]. Hence, the not extensively studied outdoor site features of public housing communities can have perhaps as much effect on the inhabitants as buildings and landscapes in other contexts. The community planning factors of public housing and similar communities should not be considered just an aesthetic amenity.

\subsection{Limitations}

The sample of public housing communities used in this study was limited to one city of Taiwan and one example of each of the three commonly used layouts. Additional housing in other regions of the country should be investigated to increase the external validity of the findings. In addition, the three communities surveyed are all military-dependent communities, which is the most popular type of public housing in Taiwan. It is possible the behaviors of military dependents differ from those of residents in other types of public housing. Culture and residential density (average of the 3 sites $8589 \mathrm{p} / \mathrm{km}^{2}$ ), which were not include in the study, could affect the behaviors tested. Studies in the future could include residential density or culture as predictors, or compare the difference of the behaviors under different culture or density.

\section{Conclusions}

Community planning factors were found to have significant connections with the three dimensions of place relationships investigated in this study. Although not often investigated, residents' levels of satisfaction with small-scale features were linked with these three psychological and sociological dimensions, namely place attachment, social interaction, and community participation. The community planning factors investigated could be grouped into four different factors, specifically those dealing outdoor space quality, circulation planning, outdoor recreational facilities, as well as community layout and administration. These four planning factors were revealed to be associated with different combinations of the three place relationship dimensions. Outdoor space quality and community layout promote place relationships for the residents, but restrain them from community participation. Circulation planning has a positive link with place attachment and community participation, but restrains residents in social interaction. Among the three place relationship dimensions, place attachment is the most sensitive one, followed by community participation, which is affected by the planning factors. Social interaction is influenced by personal factors rather than by planning ones. The association between the community planning factors and a given place relationship dimension differed among the three community layouts, namely alley, cluster, or large courtyard. Community with the cluster layout can facilitate residents' place attachment. Depending on which dimensions one might wish to enhance, one could concentrate on changing the factor, or factors, of community planning features or using the community layout most strongly linked with those dimensions. Our hope is that the findings of this study can be utilized by architects, landscape architects, urban planners, and city management to improve the emotional and social experiences of public housing and similar residential communities.

Author Contributions: H.Z. conceived and designed the study; R.H.M. analyzed the data and wrote the paper; Y.-J.H. conducted the survey.

Funding: This research was funded by a grant from the Ministry of Science and Technology Taiwan with the project number: NSC-102-2511-S-006-001.

Conflicts of Interest: The authors declare no conflict of interest. The funders had no role in the design of the study; in the collection, analyses, or interpretation of data; in the writing of the manuscript, and in the decision to publish the results. 


\section{References}

1. Dekker, K. Social capital, neighbourhood attachment and participation in distressed urban areas. A case study in The Hague and Utrecht, The Netherlands. Hous. Stud. 2007, 22, 355-379. [CrossRef]

2. Aiello, A.; Ardone, R.G.; Scopelliti, M. Neighbourhood planning improvement: Physical attributes, cognitive and affective evaluation and activities in two neighbourhoods in Rome. Eval. Progr. Plan. 2010, 33, $264-275$. [CrossRef] [PubMed]

3. Hur, M.; Nasar, J.L.; Chun, B. Neighborhood satisfaction, physical and perceived naturalness and openness. J. Environ. Psychol. 2010, 30, 52-59. [CrossRef]

4. Sundblad, D.R.; Sapp, S.G. The persistence of neighboring as a determinant of community attachment: A community field perspective. Rural Sociol. 2011, 76, 511-534. [CrossRef]

5. Bougouffa, I.; Permana, A.S. A study on the linkages between residential satisfaction and the overall quality of life in Bandar Tun Razak area of Kuala Lumpur city, Malaysia. Appl. Res. Qual. Life 2017, 1-23. [CrossRef]

6. Lewicka, M. Place attachment: How far have we come in the last 40 years? J. Environ. Psychol. 2011, 31, 207-230. [CrossRef]

7. Brügger, A.; Dessai, S.; Devine-Wright, P.; Morton, T.A.; Pidgeon, N.F. Psychological responses to the proximity of climate change. Nat. Clim. Chang. 2015, 5, 1031. [CrossRef]

8. Anton, C.E.; Lawrence, C. Home is where the heart is: The effect of place of residence on place attachment and community participation. J. Environ. Psychol. 2014, 40, 451-461. [CrossRef]

9. Belanche, D.; Casaló, L.V.; Flavián, C. Understanding the cognitive, affective and evaluative components of social urban identity: Determinants, measurement, and practical consequences. J. Environ. Psychol. 2017, 50, 138-153. [CrossRef]

10. Dekker, K.; Van Kempen, R. Places and participation: Comparing resident participation in post-wwii neighborhoods in northwest, central and southern Europe. J. Urban Aff. 2008, 30, 63-86. [CrossRef]

11. Ziersch, A.; Osborne, K.; Baum, F. Local community group participation: Who participates and what aspects of neighbourhood matter? Urban Policy Res. 2011, 29, 381-399. [CrossRef]

12. Mantey, D. The 'publicness' of suburban gathering places: The example of Podkowa Leśna (Warsaw Urban Region, Poland). Cities 2017, 60, 1-12. [CrossRef]

13. Arnberger, A.; Eder, R. The influence of green space on community attachment of urban and suburban residents. Urban For. Urban Green. 2012, 11, 41-49. [CrossRef]

14. Lincoln, N.K.; Ardoin, N.M. Cultivating values: Environmental values and sense of place as correlates of sustainable agricultural practices. Agric. Hum. Values 2016, 33, 389-401. [CrossRef]

15. Shumaker, S.A.; Taylor, R.B. Toward a clarification of people-place relationships: A model of attachment to place. Environ. Psychol. Dir. Perspect. 1983, 2, 19-25.

16. Scannell, L.; Gifford, R. Place attachment enhances psychological need satisfaction. Environ. Behav. 2017, 49, 359-389. [CrossRef]

17. Kil, N.; Holland, S.M.; Stein, T.V.; Ko, Y.J. Place attachment as a mediator of the relationship between nature-based recreation benefits and future visit intentions. J. Sustain. Tour. 2012, 20, 603-626. [CrossRef]

18. Proshansky, H.M. The city and self-identity. Environ. Behav. 1978, 10, 147-169. [CrossRef]

19. Ratcliffe, E.; Korpela, K.M. Time-and self-related memories predict restorative perceptions of favorite places via place identity. Environ. Behav. 2018, 50, 690-720. [CrossRef]

20. Stokols, D. People in places: A transactional view of settings. In Cognition Social Social Environment Environment; Lawrence Erlbaum: Hillsdale, NJ, USA, 1981; pp. 441-488.

21. Wynveen, C.J.; Schneider, I.E.; Arnberger, A. The context of place: Issues measuring place attachment across urban forest contexts. J. For. 2018, 116, 367-373. [CrossRef]

22. Moulay, A.; Ujang, N.; Maulan, S.; Ismail, S. Understanding the process of parks' attachment: Interrelation between place attachment, behavioural tendencies, and the use of public place. City Cult. Soc. 2017. [CrossRef]

23. Dmochowska-Dudek, K.; Bednarek-Szczepańska, M. A profile of the polish rural nimbyist. J. Rural Stud. 2018, 58, 52-66. [CrossRef]

24. Cahuas, M.C.; Wakefield, S.; Peng, Y. Social change or business as usual at city hall? Examining an urban municipal government's response to neighbourhood-level health inequities. Soc. Sci. Med. 2015, 133, 366-373. [CrossRef] [PubMed] 
25. Stefaniak, A.; Bilewicz, M.; Lewicka, M. The merits of teaching local history: Increased place attachment enhances civic engagement and social trust. J. Environ. Psychol. 2017, 51, 217-225. [CrossRef]

26. Hashemnezhad, H.; Heidari, A.A.; Mohammad Hoseini, P. "Sense of place" and "place attachment". Int. J. Archit. Urban Dev. 2013, 3, 5-12.

27. Di Masso, A.; Dixon, J.; Hernández, B. Place attachment, sense of belonging and the micro-politics of place satisfaction. In Handbook of Environmental Psychology and Quality of Life Research; Springer: Cham, Switzerland, 2017; pp. 85-104.

28. Kim, J.; Kaplan, R. Physical and psychological factors in sense of community: New urbanist Kentlands and nearby Orchard village. Environ. Behav. 2004, 36, 313-340. [CrossRef]

29. Lewicka, M. What makes neighborhood different from home and city? Effects of place scale on place attachment. J. Environ. Psychol. 2010, 30, 35-51. [CrossRef]

30. De la Barrera, F.; Reyes-Paecke, S.; Harris, J.; Bascuñán, D.; Farías, J.M. People's perception influences on the use of green spaces in socio-economically differentiated neighborhoods. Urban For. Urban Green. 2016, 20, 254-264. [CrossRef]

31. Wilkerson, A.; Carlson, N.E.; Yen, I.H.; Michael, Y.L. Neighborhood physical features and relationships with neighbors: Does positive physical environment increase neighborliness? Environ. Behav. 2012, 44, 595-615. [CrossRef]

32. Zhu, X.; Yu, C.-Y.; Lee, C.; Lu, Z.; Mann, G. A retrospective study on changes in residents' physical activities, social interactions, and neighborhood cohesion after moving to a walkable community. Prev. Med. 2014, 69, S93-S97. [CrossRef] [PubMed]

33. Waygood, E.O.D.; Friman, M.; Olsson, L.E.; Taniguchi, A. Children's incidental social interaction during travel international case studies from Canada, Japan, and Sweden. J. Trans. Geogr. 2017, 63, 22-29. [CrossRef]

34. Can, I.; Heath, T. In-between spaces and social interaction: A morphological analysis of Izmir using space syntax. J. Hous. Built Environ. 2016, 31, 31-49. [CrossRef]

35. Uslu, A. Social interaction in urban transformation areas and the characteristics of urban outdoor spaces: A case study from Turkey. Afr. J. Agric. Res. 2010, 5, 2801-2810.

36. Sullivan, W.C.; Kuo, F.E.; Depooter, S.F. The fruit of urban nature: Vital neighborhood spaces. Environ. Behav. 2004, 36, 678-700. [CrossRef]

37. Bratina Jurkovič, N. Perception, experience and the use of public urban spaces by residents of urban neighbourhoods. Urbani Izziv 2014, 25, 107-125. [CrossRef]

38. Jung, E.; Lee, J.; Kim, K. The relationship between pedestrian environments and sense of community in apartment complexes in Seoul, Korea. J. Asian Archit. Build. Eng. 2015, 14, 411-418. [CrossRef]

39. Corcoran, J.; Zahnow, R.; Wickes, R.; Hipp, J. Neighbourhood land use features, collective efficacy and local civic actions. Urban Stud. 2017, 55, 2372-2390. [CrossRef]

40. Matthews, P. Being strategic in partnership-interpreting local knowledge of modern Local Government. Local Gov. Stud. 2014, 40, 451-472. [CrossRef]

41. Todd, N.R.; Boeh, B.A.; Houston-Kolnik, J.D.; Suffrin, R.L. Interfaith groups as mediating structures for political action: A multilevel analysis. Am. J. Community Psychol. 2017, 59, 106-119. [CrossRef] [PubMed]

42. Hair, J.; Anderson, R.; Babin, B.; Black, W. Multivariate data analysis: A global perspective. N. J. Pearson 2010, 7, 816.

43. Scheaffer, R.L.; Mendenhall, W., III; Ott, R.L.; Gerow, K.G. Elementary Survey Sampling; Cengage Learning: Boston, MA, USA, 2011.

44. Scopelliti, M.; Carrus, G.; Adinolfi, C.; Suarez, G.; Colangelo, G.; Lafortezza, R.; Panno, A.; Sanesi, G. Staying in touch with nature and well-being in different income groups: The experience of urban parks in Bogotá. Landsc. Urban Plan. 2016, 148, 139-148. [CrossRef]

45. Abass, Z.I.; Tucker, R. Residential satisfaction in low-density Australian suburbs: The impact of social and physical context on neighbourhood contentment. J. Environ. Psychol. 2018, 56, 36-45. [CrossRef]

46. Lo, A.Y.; Jim, C. Community attachment and resident attitude toward old masonry walls and associated trees in Urban Hong Kong. Cities 2015, 42, 130-141. [CrossRef]

47. Lund, H. Pedestrian environments and sense of community. J. Plan. Educ. Res. 2002, 21, 301-312. [CrossRef]

48. Riazi, M.; Emami, A. Residential satisfaction in affordable housing: A mixed method study. Cities 2018. [CrossRef] 
49. Toruńczyk-Ruiz, S.; Lewicka, M. Perceived social diversity and neighbourhood attachment: The role of intergroup ties and affective appraisals of the environment. Evidence from Poland. Eur. J. Soc. Psychol. 2016, 46, 818-832. [CrossRef]

50. Chen, Y.-L. Taiwan in dire need of real social housing. Taipei Times, 20 February 2012; 8.

51. Buys, L.; Miller, E. Residential satisfaction in inner urban higher-density Brisbane, Australia: Role of dwelling design, neighbourhood and neighbours. J. Environ. Plan. Manag. 2012, 55, 319-338. [CrossRef]

52. Hansen, G. Design for healthy communities: The potential of form-based codes to create walkable urban streets. J. Urban Des. 2014, 19, 151-170. [CrossRef]

53. Polanski, N. Reimagining the right-of-way: Designing streets as environmental and economic assets for active living and healthy environments. Trans. Res. Rec. 2015, 139-148. [CrossRef]

54. Williams, D.R.; Vaske, J.J. The measurement of place attachment: Validity and generalizability of a psychometric approach. For. Sci. 2003, 49, 830-840.

55. Buckner, J.C. The development of an instrument to measure neighborhood cohesion. Am. J. Community Psychol. 1988, 16, 771-791. [CrossRef]

56. Boessen, A.; Hipp, J.R.; Smith, E.J.; Butts, C.T.; Nagle, N.N.; Almquist, Z. Networks, space, and residents' perception of cohesion. Am. J. Community Psychol. 2014, 53, 447-461. [CrossRef] [PubMed]

57. Christens, B.D.; Speer, P.W.; Peterson, N.A. Assessing community participation: Comparing self-reported participation data with organizational attendance records. Am. J. Community Psychol. 2016, 57, 415-425. [CrossRef] [PubMed]

58. Elliott, J.; Gale, C.R.; Parsons, S.; Kuh, D.; Team, H.S. Neighbourhood cohesion and mental wellbeing among older adults: A mixed methods approach. Soc. Sci. Med. 2014, 107, 44-51. [CrossRef] [PubMed]

59. Simonsen, W. Citizen Participation in Resource Allocation; Routledge: Abingdon, UK, 2018.

60. Devine-Wright, P. Think global, act local? The relevance of place attachments and place identities in a climate changed world. Glob. Environ. Chang. 2013, 23, 61-69. [CrossRef]

61. Lyon, C. Place systems and social resilience: A framework for understanding place in social adaptation, resilience, and transformation. Soc. Natl. Res. 2014, 27, 1009-1023. [CrossRef]

62. Foster-Fishman, P.G.; Cantillon, D.; Pierce, S.J.; Van Egeren, L.A. Building an active citizenry: The role of neighborhood problems, readiness, and capacity for change. Am. J. Community Psychol. 2007, 39, 91-106. [CrossRef] [PubMed]

63. Rice, L.J.; Hughes, B.; Briggs, V.; Delmoor, E.; Jefferson, M.; Johnson, J.C.; Halbert, C.H. Perceived efficacy and control for neighborhood change: The cross-cutting role of collective efficacy. J. Racial Ethn. Health Disparities 2016, 3, 667-675. [CrossRef] [PubMed]

64. Zhang, H.; Lei, S.L. A structural model of residents' intention to participate in ecotourism: The case of a wetland community. Tour. Manag. 2012, 33, 916-925. [CrossRef]

65. Levasseur, M.; Généreux, M.; Bruneau, J.-F.; Vanasse, A.; Chabot, É.; Beaulac, C.; Bédard, M.-M. Importance of proximity to resources, social support, transportation and neighborhood security for mobility and social participation in older adults: Results from a scoping study. BMC Public Health 2015, 15, 503. [CrossRef] [PubMed]

66. Heschong, L. Daylight and Retail Sales; Heschong Mahone Group: Gold River, CA, USA; California Energy Commission: Sacramento, CA, USA, 2003.

67. O'Donnell, P.A. Building Student Success: School Conditions and Student Achievement; Wilmington University (Delaware): Ann Arbox, MI, USA, 2016.

68. White, J.T. Foundations of School Stakeholder's Perceptions Related to School Building Conditions and Learning. Ph.D. Thesis, Walden University, Minneapolis, MN, USA, 2011.

69. Hodson, C.B.; Sander, H.A. Green urban landscapes and school-level academic performance. Landsc. Urban Plan. 2017, 160, 16-27. [CrossRef]

(C) 2018 by the authors. Licensee MDPI, Basel, Switzerland. This article is an open access article distributed under the terms and conditions of the Creative Commons Attribution (CC BY) license (http:/ / creativecommons.org/licenses/by/4.0/). 